\title{
Risk Management Functions and Audit Report Lag among Listed Saudi Manufacturing Companies
}

\author{
Waddah Kamal Hassan OMER ${ }^{1}$, Khaled Salmen ALJAAIDI ${ }^{2}$, Ehsan Saleh AL-MOATAZ ${ }^{3}$
}

Received: June 05, 2020 Revised: June 14, 2020 Accepted: July 09, 2020

\begin{abstract}
This paper examines whether the combination of risk management and audit committee functions are associated with audit report lag. Audit report lag is considered an important aspect of the financial reporting. The financial reports are the main source of information for shareholders through which they make their decisions and it assists in reducing the information asymmetry. As the internal control mechanisms substitute the external ones, the internal board committees formed by the board of directors can reduce the audit work and, consequently, reduces the audit report lag. A key committee is the risk management committee. This paper examines whether the combination of risk management and audit committee functions are associated with audit report lag. We posit that a combination of such functions in one committee refereed as audit committee affects the audit report delay. Data were obtained from 198 manufacturing companies listed on the Saudi Stock Exchange (Tadawul) for the years 2016-2018. A pooled OLS regression analysis shows that a combination of risk management and audit committee functions in a stand-alone committee named "audit committee" is associated with longer audit report lag. The outcomes suggest companies should prioritize the establishment of standalone risk management committee with activities separated from those of audit committees.
\end{abstract}

Keywords : Risk Management, Audit Committee, Audit Report Lag, Saudi Arabia

JEL Classification Code : G32, M42

\section{Introduction}

One of the most important aspects of the financial reporting is the timeliness (McGee \& Tarangelo, 2008; Sultana, Singh, \& Van der Zahn, 2015; Ika \& Ghazali, 2012; Abbott, Parker, \& Peters, 2012; Nelson \& Shukeri, 2011). Al-Ajmi (2008) reports that shareholders in the emerging countries rely on financial reporting as a main source of

${ }^{1}$ First Author and Corresponding Author. [1] Assistant Professor, Department of Accounting, College of Business Administration, Northern Border University, Saudi Arabia; [2]Accounting Department, Faculty of Administrative Sciences, University of Aden, Yemen [Postal Address: Al-Khalij District, Turaif Governorate, 75311-4578, Kingdom of Saudi Arabia] Email: waddahkam@yahoo.com

${ }^{2}$ Assistant Professor, Accounting Department, College of Business Administration, Prince Sattam bin Abdulaziz University, Saudi Arabia. Email: k.aljaaidi@psau.edu.sa

${ }^{3}$ Professor, Accounting Department, College of Business Administration, Umm Al-Gura University, Saudi Arabia. Email: esmoataz@uqu.edu.sa

(c) Copyright: The Author(s)

This is an Open Access article distributed under the terms of the Creative Commons Attribution Non-Commercial License (http://Creativecommons.org/licenses/by-nc/4.0/) which permits unrestricted noncommercial use, distribution, and reproduction in any medium, provided the original work is properly cited. information. Khasharmeh and Aljifri (2010) argue that audit report lag (ARL) plays an important role for emerging economies as news conferences, media releases and financial analysts' forecasts are not well developed. Additionally, the regulatory bodies are not as effective as their western counterparts (Wallace \& Briston, 1993; Chahine \& Tohme, 2009). As a consequence, shareholders base their decisions on the timely published and audited financial statements (Piot, 2008). The critical role played by ARL as seen in prior studies has been tested in varying contexts, but has yet to be settled and are facing limited results (Leventis, Weetman, \& Caramanis, 2005; Che-Ahmed \& Abidin 2008; El-Bannany, 2008; Lee, Mande, \& Son, 2008; Afify, 2009; Khasharmeh \& Aljifri, 2010; Mohamad-Nor, Shafie, \& Wan-Hussin, 2010; Hashim \& Abdul Rahman, 2011). A single matter that has existed and is overlooked by researchers in the field of ARL is corporate governance mechanism (e.g., risk management committee), which handles the monitoring of financial reporting procedures and the enhancement of quality financial reporting. In fact, the risk management committee (RMC) used to play a minor role and was not regarded as having any great significance by companies. Risk management needs were incorporated into the remit of the audit committee. 
Within Saudi Arabia, the Code of Corporate Governance (2006) does not allocate risk management roles to audit committees; rather it is incorporated into the chief responsibilities of the board of directors. Under the Saudi Arabia code, a company is given the choice of whether it wishes to create a subcommittee, depending on the requirements of the business; it is not mandatory. Audit committees are regarded as being able to encompass internal controls and risk management as well as guaranteeing that financial reports have transparency and integrity. However, this is dependent on the way a company organizes its corporate governance. In addition, audit companies participate in a number of areas related to risk, including risk control, management, evaluation, and identification. In spite of this, and the fact that audit committees are supposed to protect the interests of shareholders, they frequently have become involved in corporate failings and indeed scandal. Within Saudi Arabia, existing manufacturing firms have not established a standalone risk management committee. Though presenting their annual reports, the risk management activities are combined with audit committee functions (Alzharani \& Aljaaidi, 2015).

It further enhances the idea that a risk management committee, as the sole manager of risks, increases the efficiency of the risk management data in comparison with the audited committee taking over and handling both its role and those assigned to the risk management committee (Bates \& Leclerc, 2009). Zaman's (2001) study reveals how the audit committee is expected to perform well with limited resources. The audit committee must conduct extensive research on the data they have; this requires quite some time to get finished. Also, some of these committees may not have a workforce with the proper skills to carry out their duties. Zaman's study also shows how to audit report lags come to be due to factors that are more or less controllable by the auditor. Burton (2008) documents that risk is not only a depiction characterized from a financial angle; it additionally identified with legislative, economy, politics, and market issues. This is evident as a business governed around the prior factors, which influence its growth or demise once established.

The independence of an audit committee from a risk management committee is recommended (Bugalla, Kallman, Lindo, \& Narvaez, 2012). To keep up its uprightness and insurance against misbehavior, this visualizes the criticality of the independence between an audit committee from the risk management committee as a firm that separates these two tend to function with much ease as compared to a firm that grouped them as a single entity. $\mathrm{Ng}$, Chong and Ismail (2013) mentioned the foundation of sovereign RMC.

Bugalla et al. (2012) have proposed that audit committees should be separated from RMC so that their integrity can be maintained and provide a buffer against financial wrongdoing. As this environment has complex dynamics, Ng, Chong and Ismail (2013) proposed that RMCs should be given independence, something echoed by Brown and Caylor (2009), whose work noted that audit committees do not necessarily have the capabilities of being able jointly monitor all risks, financial and otherwise. In addition, Brown, Steen and Foreman (2009) stated that the audit committee must have a complete understanding of the risk management system, so that it can assume responsibility for overseeing risk. Many researchers are of the opinion that independent RMCs would enhance companies' internal control mechanisms (Yatim, 2010). Alzahrani and Aljaaidi (2015) examined the link between audit committee characteristics and the combination of risk management and audit committee activities in Saudi Arabia. Subramaniam, McManus and Zhang (2009) examined the relationship between the RMC establishments and the company's characteristics and board factors. He noted that an independent RMC favored the running of the firm as opposed to not having one, making it more or less difficult to assess risks within a stipulated time. This showed the substantial impact that an RMC has within a firm. Also, Yatim (2009; 2010) directed comparable research in the Malaysian context while Bugalla et al. (2012) came up with a method of governing and dealing with risks in the financial field that will be of help to all the auditors. Aside from this, the lack of research was brought into existence by Tufano (1996). He argued that there was no enough data that could be used to determine how risky a situation might be; all the data that was used to reach the conclusion was not enough.

The paucity of research on risk management and corporate governance is the motivation for this study: to examine the combination of risk management and audit committee activities in the setting of Saudi manufacturing companies. This is due to the vulnerability of the industrial sector to various sorts of risks in the country, region and worldwide business environments. Primarily, the study looks at whether or not the combination of risk management and audit committee activities is associated with ARL. The lack of a standalone risk management committee dealing with risk activities would affect the delay of ARL. The use of Saudi Arabia as a context to the address the study objective is based on several factors. Previous studies have not shown any link between the combination of audit and risk management committee functions and report lag in Saudi Arabia. Also, ARL is a considerable issue in emerging economies while other nonfinancial statements such as news meetings, media discharges, and financially-related investigators' forecasts are not very much developed as they are still undergoing a growth surge in their respective fields of development (Wallace \& Briston, 1993; Chahine \& Tohme, 2009). Hence, these markets have a longer time lag (Khasharmeh \& Aljifri, 2010). The research adds to the audit literature by looking at the relationship in the combination of audit committee and risk management committee purposes and ARL.

The objective of this study is to examine whether the combination of audit committee and risk management 
committee functions could assist in reducing ARL. Such examination is important since no previous studies examined this relationship in the Saudi context. Hence, this study aims to answer the following research question: "Could risk management committee reduce company's ARL?"

The rest of this paper is structured as follow. The next section illustrates the research design and model specification Section four provides the results of the analysis and discussion. The final section concludes and discuses limitations and suggestion for future research.

\section{Research Design and Model Specification}

This hypothesis of this study is developed based on the discussions highlighted in the previous section. Specifically, this research will examine whether there is a relationship between the ARL and combining the duties of audit committees and risk managers. When separate RMCs are not present with specific responsibilities for managing risk, this may provoke delays in ARL. Therefore, the hypothesis developed by this study is stated in the following direct form:

$\boldsymbol{H}_{I}$ : There is a positive relationship between the combination of risk management and audit committees' functions and the audit report lag.

The population relevant to the study is all manufacturing companies listed on the Saudi Stock Exchange (Tadawul) for the years 2016-2018. This selection is the most recent test period for which data were available at the time this study is carried out. Further, the boom of Saudi Arabia clearly emerged in early 2005 (Chahine \& Tohme, 2009). A crosssectional review of audit reports of the sampled companies listed on Saudi Stock Exchange was undertaken. Samples selected are depicted in Table 1.

Table 1: Sample Selection

\begin{tabular}{|l|c|}
\hline & Total Observations \\
\hline Total observations & 201 \\
\hline $\begin{array}{l}\text { Observations discarded (outliers, } \\
\text { missing and incomplete data) }\end{array}$ & $(3)$ \\
\hline Final sample & 198 \\
\hline
\end{tabular}

To minimize the effect of the expunged variables and to increase the predictive ability of the model we include several control variables. The control variables are classified into two groups. Firstly, the Corporate governance control variables, namely, board of directors' effectiveness (BDE) and audit committee effectiveness (ACE); secondly, the firm characteristics control variables, namely, firm size (SIZE), firm performance (ROA), leverage (LEV), and firm age (AGE). Prior studies have uncovered that those variables are associated with audit report lag (Knechel \& Sharma, 2012; Dao \& Pham, 2014; Hassan, 2016; Meckfessel \& Sellers, 2017; Samaha \& Khlif, 2017, Habib \& Muhammadi, 2018; Farag, 2017; Wan Hussin, Bamahros, \& Shukeri,2018; Abdillah, Mardijuwono, \& Habiburrochman, 2019; Mathuva, Tauringana, \& Owino, 2019; Aljaaidi, Omer, \& Bagulaidah, 2019; Baatwah, Salleh, \& Stewart, 2019; Chae, Nakano, \& Fujitani, 2020; Ha, \& Nguyen, 2020; Nguyen, \& Nguyen, 2020).

With regard to the corporate governance control variables, we include the board of directors' effectiveness BDE (board size and meetings) and audit committee effectiveness ACE (audit committee size and meetings). Most prior archival studies have documented that the effectiveness of the corporate governance mechanisms is associated with audit report lag (DeZoort, Hermanson, \& Archabeault 2002; Baatwah, Salleh, \& Ahmad, 2015; Hassan, 2016; Farag, 2017; Samaha \& Khlif, 2017; Oussii \& Taktak, 2018; Wan Hussin et al. 2018; Mathuva, et al., 2019; Aljaaidi et al., 2019; Baatwah et al., 2019; Abdillah, Mardijuwono, \& Habiburrochman, 2019; Dang, Pham, Nguyen, \& Nguyen,2020). With regard to the firm-specific control variables, prior studies have documented that the company size (SIZE), company performance (ROA), leverage (LEV), and company age (AGE) are significantly associated with audit report lag. (Soltani, 2002, Afify, 2009; Dao \& Pham, 2014; Baatwah et al., 2015; Alfraih. 2016; Hassan, 2016; Farag, 2017; Meckfessel \& Sellers; 2017; Rusmin \& Evans, 2017; Samaha \& Khlif, 2017; Habib \& Muhammadi, 2018; Khoufi \& Khoufi. 2018; Oussii \& Taktak, 2018; Ocak \& Özden, 2018; Akingunola, Soyemi, \& Okunuga, 2018; Mathuva, et al., 2019 Abdillah et al., 2019; Aljaaidi et al., 2019; Stewart \& Cairney 2019). The following is the hypothesized audit report lag (ARL) model:

\begin{tabular}{|c|c|c|}
\hline \multicolumn{3}{|c|}{$\begin{array}{l}\mathrm{ARL}=\beta 0+\beta 1 \mathrm{RMC}+\text { Control variables }+\varepsilon \ldots \ldots \ldots \ldots \ldots \ldots \ldots \ldots \ldots \ldots \ldots \ldots \ldots \ldots \ldots \ldots \ldots \ldots \ldots \ldots \\
\text { Where: }\end{array}$} \\
\hline ARL & $=$ & a number of calendar days from fiscal year- end to the date of the auditor's report, \\
\hline \multicolumn{3}{|c|}{ Test variable } \\
\hline RMC & $=$ & $\begin{array}{l}\text { " } 1 \text {," if the functions of the risk management committee are combined with the audit committee functions, } \\
\text { and " } 0 \text {," otherwise. }\end{array}$ \\
\hline
\end{tabular}




\begin{tabular}{|l|c|l|}
\hline \multicolumn{2}{|l|}{ Control variables } \\
\hline BDE & $=$ & An integration of board size and board meetings, \\
\hline ACE & $=$ & An integration of audit committee size and audit committee meetings, \\
\hline SIZE & $=$ & $\log _{10}$ of the total assets, \\
\hline LEV & $=$ & total debt to total assets, \\
\hline ROA & $=$ & net income divided by book value of total assets, \\
\hline AGE & $=$ & the number of years since the company is established, \\
\hline e & $=$ & error term. \\
\hline
\end{tabular}

\section{Results}

\subsection{Descriptive Statistics and Correlation Analysis}

Table 2 reports the descriptive statistics of all variables investigated in this study. The mean of the number of calendar days from fiscal-year end to date of external auditor's report (ARL) is 55 days (standard deviation of 20.915 days) with actual minimum of 9 days and maximum of 92 days. This means that the Saudi listed companies take approximately 55 days on average beyond their annual reports date before they are finally ready for the presentation of the audited financial reports to the shareholders. This evidence suggests that the ARL may be an important concern for Saudi listed companies in financial reporting policy when compared with other Arab countries. It is important to mention that the average audit report lag of Egyptian companies is 67 days as reported by Afify (2009) and similar to audit lag in Bahrain (51 days), but longer than average audit lag in United Arab Emirates (43 days), as reported by Khasharmeh and Aljifri (2010).

With regard to corporate governance variables, Table 2 shows that the mean of the board of directors' effectiveness
(BDE) is approximately 41.48 with a standard deviation of 14.55. As for the audit committee effectiveness (ACE), the average is approximately 19.54 with a standard deviation of 7.39. With respect to the firm size (SIZE), the mean is S.R 7407152584.50 with a maximum of S.R 97073302267.00, a minimum of S.R 19084462.00 and a standard deviation of 46168347.746. With respect to firm leverage (LEV), it ranges from 0.02 to 8.90 with an average of 0.44 and a standard deviation of 0.65 . The firm performance (ROA) ranges from 0.00 to 0.92 with an average of 0.06 and a standard deviation of 0.10 . In terms of firm age (AGE), the average is approximately 28.03 and a standard deviation is 14.19 .

\subsection{Multivariate Analysis}

Table 3 shows the multiple regression results. As seen from Table 3, the model explains $10.7 \%$ of the variation in ARL. In general, the model is significant $(\mathrm{F}=3.017)$ (Sig $F=0.005)$. As for the association between the RMC and ARL, the direction of this relationship is positive and marginal significant at $5 \%(\beta=4.726, t=1.480, \mathrm{P}=.070$, one-tailed significance). This result indicates a positive relationship between RMC and ARL at 10\% level, which

Table 2: Descriptive Statistics

\begin{tabular}{|c|c|c|c|c|}
\hline \multicolumn{5}{|c|}{ Panel A: Continuous variables } \\
\hline Variable & Minimum & Maximum & Mean & Std.Deviation \\
\hline ARL & 9.00 & 92.00 & 55.1818 & 20.91528 \\
\hline BDE & 10.00 & 91.00 & 41.48 & 14.55 \\
\hline ACE & 6.00 & 49.00 & 19.54 & 7.39 \\
\hline SIZE & 19084462.00 & 97073302267.00 & 7407152584.50 & 15434611416.22 \\
\hline LEV & 0.02 & 8.90 & 0.44 & 0.65 \\
\hline ROA & 0.00 & 0.92 & 0.06 & 0.10 \\
\hline AGE & 2.00 & 62.00 & 28.03 & 14.19 \\
\hline \multicolumn{5}{|c|}{ Panel B: Dichotomous variables } \\
\hline \multicolumn{2}{|l|}{ Variable } & \multicolumn{2}{|c|}{ A combined function (\%) } & Not combined (\%) \\
\hline \multicolumn{2}{|c|}{ A combination function of $A C$ \& RM } & \multicolumn{2}{|c|}{$36(35)$} & $66(65)$ \\
\hline
\end{tabular}


Waddah Kamal Hassan OMER, Khaled Salmen ALJAAIDI, Ehsan Saleh AL-MOATAZ I

Journal of Asian Finance, Economics and Business Vol 7 No 8 (2020) 061-067

Table 3: OLS Regression Results

\begin{tabular}{|c|c|c|c|c|c|c|c|}
\hline Variable & $\begin{array}{l}\text { Expected } \\
\text { Sign }\end{array}$ & $\beta$ & Std. Error & T-Value & P-value & Tolerance & VIF \\
\hline Constant & & 78.030 & 22.883 & 3.410 & 0.001 & & \\
\hline \multicolumn{8}{|l|}{ Test Variable } \\
\hline RMC & + & 4.726 & 3.194 & 1.480 & 0.141 & 0.927 & 1.079 \\
\hline \multicolumn{8}{|c|}{ Control Variables } \\
\hline BDE & & 0.098 & 0.117 & 0.838 & 0.403 & 0.770 & 1.299 \\
\hline ACE & & -0.140 & 0.222 & -0.630 & 0.529 & 0.829 & 1.206 \\
\hline SIZE & & -3.422 & 2.365 & -1.447 & 0.150 & 0.921 & 1.086 \\
\hline LEV & & 4.687 & 2.270 & 2.065 & 0.040 & 0.970 & 1.031 \\
\hline ROA & & -49.166 & 14.560 & -3.377 & 0.001 & 0.921 & 1.086 \\
\hline AGE & & 0.200 & 0.113 & 1.771 & 0.078 & 0.831 & 1.203 \\
\hline
\end{tabular}

$\mathrm{DV}=\mathrm{ARL} \mathrm{R}^{2}=.107$ Adjusted $\mathrm{R}^{2}=.072 \mathrm{~F}$-Ratio $=3.017 \mathrm{Sig} \mathrm{F}=.005$

means the more the combination of the risk management committee's activities with audit committee activities, the higher the increase in the ARL. This result is consistent with agency theory prediction and the suggestions indicated by (Hermanson, 2003; Yatim, 2009; Alzharani \& Aljaaidi, 2015). Thus, we accept hypothesis 1.

\section{Conclusion}

The findings of this study shows that the combination of risk management and audit committees activities increases the audit report lag among listed manufactured companies in Saudi Arabia. The importance of risk management committee tasks influencing audit reports in Saudi Arabia is brought to light by this result. Hence, manufacturing companies have to prioritize the establishment of standalone risk management committee with activities separated from those of audit committees. The shortcomings of the research lie in other internal corporate governance (a board of directors' characteristics, audit committee characteristics, and ownership structure). Future research should attempt at introducing these mechanisms and look at them singularly or combine them to get a better perspective on their impact. An extensive study should imitate this model to ascertain its authenticity in diverse contexts of GCC countries, regulating periods on when they are carried out, and with distinct sample sizes each time the experiment is carried out. The drawbacks may generate the necessary motivation for future research in the GCC market.

The issue of audit report lags in Saudi Arabia is addressed by the inference of these findings emphasizing the importance of splitting audit committee tasks from RMC tasks. Additional insight is useful to the Saudi government, stock market, companies, accounting, and auditing regulators in terms of comprehending the bases influencing audit report lag. Allowing them to place countermeasures to the problems they tend to experience caused by the audit report lags. Banks usually tend to look for a way on how they can calculate the financial stability of companies that are willing to merge in the realm of Saudi Arabia by completing this exploration. The report submitted on the financial statements is highly linked to mandate bond agreements.

Additionally, a lender's maximum borrowing amount is usually based on the reports filed by the auditors' financial statements. This makes audit report lags issues of utmost importance for lending institutions in a hurry to solve the said lag issues for the good running of the firm. Reviewed monetary statements made by the auditors are used to make informed choices relating to bonds, bond ratings, and interest rates, among other decisions relating to investing by investors and financial analysts in the Saudi Arabia market.

Consequently, an increase in the understanding and forecast of companies' events is vital to these constituencies. Additionally, the findings of this study will catch the attention of researchers and academics. The lack of a formal research body addressing the issues of audit report lag in the Saudi Arabian kingdom calls for more input. Hence, this research will offer some substantial evidence about the effects on the Saudi Arabian markets; the findings' data will be used as a basis for those who will carry out further study in this field.

\section{References}

Abbott, L.J., Parker, S. \& Peters, G.F. (2012). Internal audit assistance and external audit timeliness. Auditing: A Journal of Practice \& Theory, 34(4) 3-20. doi.org/10.2308/ajpt-10296

Abdillah, M.R., Mardijuwono, A.W., \& Habiburrochman, H. (2019). The effect of company characteristics and auditor 
characteristics to audit report lag. Asian Journal of Accounting Research, 4(1), 129-144. doi.org/10.1108/AJAR-05-2019-0042

Afify, H.A.E. (2009). Determinants of audit report lag: Does implementing corporate governance have any impact? Empirical evidence from Egypt. Journal of Applied Accounting Research, 10(1), 65-86. doi.org/10.1108/09675420910963397

Al-Ajmi, J. (2008). Audit and reporting delays: Evidence from an emerging market. Advances in Accounting, 24(2), 217-226.

Alfraih, M.M. (2016). Corporate governance mechanisms and audit delay in a joint audit regulation. Journal of Financial Regulation and Compliance, 24(3), 292-316. doi.org/10.1108/ JFRC-09-2015-0054

Aljaaidi K.S, Omer, W.K.H., \& Bagulaidah, G.S. (2019). Audit Committee Activity and Audit Report Lag in Saudia Arabia. Accounting Thought Journal, 23(3), 206-221.

Alzharani, A.M., \& Aljaaidi, K.S. (2015). An empirical investigation of audit committee effectiveness and risk management: Evidence from Saudi Arabia. Accounting \& Taxation, 7(1), 3949.

Akingunola, R.O., Soyemi, K.A., \& Okunuga, R. (2018). Client Attributes and the Audit Report Lag in Nigeria. Market Forces, 13(1). 30-41.

Baatwah, S.R., Salleh, Z., \& Ahmad, N. (2015). Corporate governance mechanisms and audit report timeliness: empirical evidence from Oman. International Journal of Accounting, Auditing and Performance Evaluation, 11(3-4), 312-337. doi. org/10.1504/IJAAPE.2015.071580

Baatwah, S.R., Salleh, Z., \& Stewart, J. (2019). Audit committee chair accounting expertise and audit report timeliness. Asian Review of Accounting 27(2), 273-306. doi.org/10.1108/ARA12-2017-0190

Bates, E.W., \& Leclerc, R.J. (2009). Boards of directors and risk committees. The Corporate Governance Advisor, 17(6), 16-18.7

Brown, L.D., \& Caylor, M.L. (2009). Corporate governance and firm operating performance. Review of Quantitative Finance and Accounting, 32(2), 129-144.† doi.org/10.1007/s11156-0070082-3

Brown, I., Steen, A., \& Foreman, J. (2009). Risk management in corporate governance: A review and proposal. Corporate Governance: An International Review, 17(5), 546-558. doi. org/10.1111/j.1467-8683.2009. 00763.x

Bugalla, J., Kallman, J., Lindo, S., \& Narvaez, K. (2012). The new model of governance and risk management for financial institutions. Journal of Risk Management in Financial Institutions, 5(2), 181-193.

Burton, E.J. (2008). The audit committee: How should it handle ERM? Journal of Corporate Accounting \& Finance, 19(4), 3-5. doi.org/10.1002/jcaf.20395

Chahine, S., \& Tohme, N.S. (2009). Is CEO duality always negative? An exploration of CEO duality and ownership structure in the Arab IPO context. Corporate Governance: An International Review, 17(2), 123-141. doi.org/10.1111/j.14678683.2008.00724.x
Chae, S.J., Nakano, M., \& Fujitani, R. (2020). Financial reporting opacity, audit quality and crash risk: evidence from Japan. Journal of Asian Finance, Economics, and Business, 7(1), 9-17. https://doi.org/10.13106/jafeb.2020.vol7.no1.9

Che-Ahmad, A., \& Abidin, S. (2008). Audit Delay of Listed Companies: A Case of Malaysia. International Business Research, 1(4), 32-39.

Dang, H.N., Pham, C.D., Nguyen, T.X., \& Nguyen, H.T.T. (2020). Effects of Corporate Governance and Earning Quality on Listed Vietnamese Firm Value. Journal of Asian Finance, Economics, and Business, 7(4), 71-80. https://doi.org/10.13106/jafeb.2020. vol7.no4.71

Dao, M., \& Pham, T. (2014). Audit tenure, auditor specialization and audit report lag. Managerial Auditing Journal, 29 (6), pp. 490-512. doi.org/10.1108/MAJ-07-2013-0906

DeZoort, F.T., Hermanson, D.R., Archabeault, D.S., \& Reed, S.A. (2002). Audit committee effectiveness: A synthesis of the empirical audit committee literature. Journal of Accounting literature, 21, 38-75

El-Bannany, M. (Spring 2008). Factors affecting audit report lag in banks: The Egyptian case. Corporate Ownership \& Control, 5(3), 54-61.

Farag, M. (2017). The impact of accelerated filing requirements on meeting audit report deadlines. Accounting Research Journal, 30(1), 58-72. doi.org/10.1108/ARJ-11-2013-0086

Ha, H.H., \& Nguyen, A.H. (2020). Determinants of Voluntary Audit of Small and Medium Sized Enterprises: Evidence from Vietnam. The Journal of Asian Finance, Economics, and Business, 7(5), 41-50. doi:10.13106/jafeb.2020.vol7.no5.041

Habib, A., \& Muhammadi, A.H. (2018). Political connections and audit report lag: Indonesian evidence. International Journal of Accounting \& Information Management, 26(1), 59-80. doi. org/10.1108/IJAIM-08-2016-0086

Hashim, U.J., \& Abdul Rahman, R. (2011). Audit report lag and the effectiveness of audit committee among Malaysian companies. International Bulletin of Business Administration, 10, 50-61.

Hassan, Y.M. (2016). Determinants of audit report lag: evidence from Palestine. Journal of Accounting in Emerging Economies, 6(1), 13-32. Doi.org/10.1108/JAEE-05-2013-0024

Hermanson, D.R. (2003). What Else in Corporate Governance Should Be Changed? Internal Auditing, 18(1), 44-45.

Ika, S.R. \& Ghazali, N.A.M. (2012). Audit committee effectiveness and timeliness of reporting: Indonesian evidence. Managerial Auditing Journal, 27(4), 403-424.

Khasharmeh, H.A., \& Aljifri, K. (2010). The timeliness of annual reports in Bahrain and the United Arab Emirates: an empirical comparative study. The International Journal of Business and Finance Research, 4(1), 51-71.

Khoufi, N., \& Khoufi, W. (2018). An empirical examination of the determinants of audit report delay in France. Managerial Auditing Journal, 33(8/9), 700-714. doi.org/10.1108/MAJ-022017-1518 
Waddah Kamal Hassan OMER, Khaled Salmen ALJAAIDI, Ehsan Saleh AL-MOATAZ /

Knechel, W.R., \& Sharma, D.S. (2012). Auditor-provided nonaudit services and audit effectiveness and efficiency: Evidence from pre-and post-SOX audit report lags. Auditing: A Journal of Practice \& Theory, 31(4), 85-114. doi.org/10.2308/ajpt-10298

Lee, H.Y., Mande, V., \& Son, M. (2008). A comparison of reporting lags of multinational and domestic firms. Journal of International Financial Management \& Accounting, 19(1), 2856. doi.org/10.1111/j.1467-646X.2008.01015.x

Leventis, S., Weetman, P., \& Caramanis, C. (2005). Determinants of audit report lag: some evidence from the Athens stock exchange. International Journal of Auditing, 9(1), 45-58. doi. org/10.1111/j.1099-1123.2005.00101.x

Mathuva, D.M., Tauringana, V., \& Owino, F.J.O. (2019). Corporate governance and the timeliness of audited financial statements. Journal of Accounting in Emerging Economies, 9(4), 473-501. doi.org/10.1108/JAEE-05-2018-0053

McGee, R.W., \& Tarangelo, T. (2008). The timeliness of financial reporting: A comparative study of Russian and Non-Russian banks. Corporate Governance in Transition Economies, 101113. doi.org/10.1007/978-0-387-

Meckfessel, M.D., \& Sellers, D. (2017). The impact of Big 4 consulting on audit reporting lag and restatements. Managerial Auditing Journal, 32(1), 19-49. doi.org/10.1108/MAJ-022016-1321

Mohamad-Nor, M.N., Shafie, R., \& Wan-Hussin, W.N. (2010). Corporate governance and audit report lag in Malaysia. Asian Academy of Management Journal of Accounting and Finance, $6(2), 57-84$.

Nelson, S.P., \& Shukeri, S.N. (2011). Corporate governance and audit report timeliness: evidence from Malaysia. Research in Accounting in Emerging Economies, 11(1), 109-127.

Nguyen, T.N.L., \& Nguyen, V.C. (2020). The Determinants of Profitability in Listed Enterprises: A Study from Vietnamese Stock Exchange. Journal of Asian Finance, Economics, and Business, 7(1), 47-58. https://doi.org/10.13106/jafeb.2020. vol7.no1.47

Ng, T.H., Chong, L.L., \& Ismail, H. (2013). Is the risk management committee only a procedural compliance? The Journal of Risk Finance, 14(1), 71-86. doi.org/10.1108/15265941311288112

Ocak, M., \& Özden, E. (2018). Signing Auditor-Specific Characteristics and Audit Report Lag: A Research from Turkey. Journal of Applied Business Research, 34(2), 277- 294.

Oussii, A.A., \& Taktak, N.B. (2018). Audit committee effectiveness and financial reporting timeliness. African Journal of Economic and Management Studies, 9(1), 34-55. doi.org/10.1108/ AJEMS-11-2016-0163
Rusmin, R., \& Evans, J. (2017). Audit quality and audit report lag: case of Indonesian listed companies. Asian Review of Accounting, 25(2), 191-210. doi.org/10.1108/ARA-06-20150062

Samaha, K., \& Khlif, H. (2017). Audit-related attributes, regulatory reforms and timely disclosure. Journal of Financial Reporting and Accounting, 15(2), 158-179. doi.org/10.1108/JFRA-082015-0077

Soltani, B. (2002). Timeliness of corporate and audit reports: some empirical evidence in the French context, The International Journal of Accounting, 37(2), 215-246. doi.org/10.1016/ S0020-7063 (02)00152-8

Stewart, E.G., \& Cairney, T.D. (2019). Audit report lag and client industry homogeneity. Managerial Auditing Journal, 34(8), 1008-1028. https://doi.org/10.1108/MAJ-07-2018-1931

Subramaniam, N., McManus, L., \& Zhang, J. (2009). Corporate governance, firm characteristics and risk management committee formation in Australian companies. Managerial Auditing Journal, 24(4), 316-339. https://doi. org/10.1108/02686900910948170

Sultana, N., Singh, H. \& Van der Zahn, J.-L.W.M. (2015). Audit committee characteristics and audit report lag. International Journal of Auditing, 19(2), 72-87. doi.org/10.1111/ijau.12033

Tufano, P. (1996). Who Manages Risk? An Empirical Examination of Risk Management Practices in the Gold Mining Industry, Journal of Finance, 51(4), 1097-1137. doi. org/10.1111/j.1540-6261.1996.tb04064.x

Wallace, R.S.O., \& Briston, R.J. (1993). Improving the accounting infrastructure in developing countries. Research in Third World Accounting, 2, 201-224.

Wan Hussin, W.N., Bamahros, H.M. \& Shukeri, S.N. (2018). Lead engagement partner workload, partner-client tenure and audit reporting lag: Evidence from Malaysia. Managerial Auditing Journal, 33(3), 246-266. https://doi.org/10.1108/MAJ-072017-1601

Yatim, P. (2009). Audit committee characteristics and risk management of Malaysian listed firms. Malaysian Accounting Review, 8(1), 19-36. dx.doi.org/10.24191/mar.v8i1.261

Yatim, P. (2010). Board structures and the establishment of a risk management committee by Malaysian listed firms. Journal of Management \& Governance, 14(1), 17-36. doi.org/10.1007/ s10997-009-9089-6

Zaman, M. (2001). Turnbull - Generating Undue Expectations of the Corporate Governance Role of Audit Committees, Managerial Auditing Journal, 16(1), 5-9. doi. org/10.1108/02686900110363429 